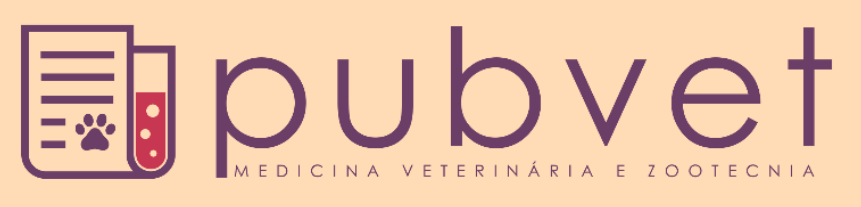

https://doi.org/10.31533/pubvet.v15n06a850.1-8

\title{
Egg pricing and labeling on supermarkets in São Paulo
}

\author{
Anna Cristina de Oliveira Souza ${ }^{1}$, Thiago Henrique da Silva ${ }^{2}$, Thiago Bernardino ${ }^{3}$, Augusto \\ Hauber Gameiro ${ }^{4 * 0}$ (D)
}

${ }^{I}$ Aluna de graduação em Medicina Veterinária da Faculdade de Medicina Veterinária e Zootecnia - FMVZ, Universidade de São Paulo - USP.

${ }^{2}$ Doutorado, Departamento de Zootecnia, Universidade de São Paulo - USP.

${ }^{3}$ Doutorado, Departamento de Medicina Veterinária Preventiva e Saúde Anima, Universidade de São Paulo - USP.

${ }^{4}$ Professor da Faculdade de Medicina Veterinária e Zootecnia - FMVZ, Universidade de São Paulo - USP.

*Autor para correspondência, E-mail: gameiro@usp.br.

\begin{abstract}
Brazil is a big table egg producer and consumer. Although battery cages are still the main production system in the country, growth in demand for specialty eggs can be identified from the growing availability of free-range and organic eggs in the market. The goal for this study was to report the prices of different table egg categories, varying in features such as eggshell color, package size or farming system, and to characterize the information available on labels. We investigated fifteen supermarket units, randomly distributed along the west side of the city of São Paulo, Brazil. Four data collections were performed throughout one year, in each unit. Our results indicate that organic eggs were the most expensive among different farming systems. Furthermore, brown shell eggs were more expensive compared to white shell eggs, regardless of the farming system. Eggs sold in small packages were more expensive than eggs sold in large packages. Cage-free and organic eggs had labels with more informative content and, lastly, eggs with more detailed labels were related to higher prices.
\end{abstract}

Keywords: Agribusiness, free range, organic, production system, traceability

\section{Preço e rotulagem de ovos em supermercados de São Paulo}

Resumo. O Brasil é um grande produtor e consumidor de ovos. Embora o sistema californiano de gaiolas ainda seja o principal sistema de produção no país, o crescimento na demanda por ovos especiais pode ser identificado a partir da crescente disponibilidade de ovos livres de gaiolas e ovos orgânicos no mercado. O objetivo deste estudo foi relatar os preços de diferentes categorias de ovos no varejo, variando em características como cor da casca, tamanho da embalagem ou sistema de produção e caracterizar as informações disponíveis nos rótulos. Nós investigamos quinze unidades de supermercados, distribuídas aleatoriamente na zona oeste da cidade de São Paulo, Brasil. Foram realizadas quatro coletas de dados ao longo de um ano em cada unidade. Nossos resultados indicam que os ovos orgânicos foram os mais caros entre as diferentes categorias de sistemas de produção avaliadas. Os ovos de casca vermelha eram mais caros em comparação com os ovos de casca branca, independentemente do sistema de produção. Ovos comercializados em embalagens pequenas eram mais caros que os vendidos em embalagens grandes. Ovos livres de gaiolas e orgânicos tiveram rótulos de embalagem mais informativos e, por fim, ovos com rótulos mais detalhados foram relacionados a preços de venda mais altos.

Palavras-chave: Agronegócio, caipira, orgânico, rastreabilidade, sistemas produtivos 


\section{Precio y etiquetado de huevos en los supermercados de São Paulo}

Resumen. Brasil es un importante productor y consumidor de huevos. Aunque el sistema de jaulas de California sigue siendo el principal sistema de producción del país, el crecimiento de la demanda de huevos especiales se puede identificar a partir de la creciente disponibilidad de huevos libres de jaulas y huevos orgánicos en el mercado. El objetivo de este estudio fue reportar los precios de diferentes categorías de huevos al por menor, variando en características como color de la cáscara, tamaño del empaque o sistema de producción y caracterizar la información disponible en las etiquetas. Investigamos quince unidades de supermercados, distribuidas aleatoriamente en el oeste de la ciudad de São Paulo, Brasil. Se realizaron cuatro recolecciones de datos durante un año en cada unidad. Nuestros resultados indican que los huevos orgánicos fueron los más costosos entre las diferentes categorías de sistemas de producción evaluados. Los huevos de cáscara roja eran más caros en comparación con los huevos de cáscara blanca, independientemente del sistema de producción. Los huevos vendidos en paquetes pequeños eran más caros que los vendidos en paquetes grandes. Los huevos orgánicos y sin jaulas tenían etiquetas de empaque más informativas y, finalmente, los huevos con etiquetas más detalladas se relacionaron con precios de venta más altos.

Palabra clave: Agroindustria, campesino, orgánico, trazabilidad, sistemas productivos

\section{Introduction}

Specialty foods are defined as foods of the highest grade, style, and/or quality in their respective categories. Their specialty nature derives from uniqueness, differentiated origin, processing method, design, limited supply, unusual application or use, extraordinary packaging, channel of distribution or sales (Tanner \& Purcell, 2010). Eggs are considered a standard of protein for its qualitative composition, crucial for the human diet, and one of the most reasonable and common food products (Buriak et al., 2018). Moreover, the production chain is dynamic and allows innovation, so eggs have been a good example of how fast the market for specialty foods is growing and how new technologies are applied to the production.

Brazil is responsible for 2,5\% of the world's egg production, and São Paulo state is the largest producer in Brazil (Kakimoto et al., 2013). In 2018, neary 31\% of the country's flock was housed in São Paulo, and the average Brazilian ate 212 eggs per year. Moreover, 99,6\% of the national production was consumed internally (ABPA, 2019). Although there are no reports on the actual change in purchasing habits for specialty eggs in Brazil, a growth in demand can be identified from growing availability of free-range and organic eggs in the market (Teixeira et al., 2018), as well as nutrient-enhanced eggs, certified for animal welfare standards, among other differentials. Growth in the specialty egg market is rapid, and organic eggs represent the fastest growing item in this category (Oberholtzer et al., 2006). However, there is a lack of information about the actual availability of specialty table eggs in Brazil and about the price differences among the eggs' categories.

The goal of this research was to investigate how the eggs market is presenting on supermarkets on the west side of the city of São Paulo, Brazil. We focused on price, categories available, and label characteristics. The questions we aimed to answer were: what kind of eggs are available on supermarkets in São Paulo's west side? How much do they cost and what are the price differences between the found categories? What kind of information is available on the label?

\section{Materials and methods}

This research was carried out upon approval of the Ethics Committee on Use of Animals (CEUA) at the School of Veterinary Medicine and Animal Science (FMVZ) of the University of São Paulo (USP), under protocol number 7547211118 .

We collected the data in the city of São Paulo, state of São Paulo, Brazil $\left(23.5719^{\circ} \mathrm{S}, 46.7008^{\circ} \mathrm{W}\right)$. Fifteen supermarket units were investigated, randomly distributed along the west side of the city. 
Throughout one year, between July of 2018 and July of 2019, we performed four collections in each supermarket unit.

The following information was analyzed: brand name, size category, eggshell color, number of eggs per package, price of the egg package, price of the egg unit, farming system, label characteristics (written information and images), and certification seals. Size categories were jumbo, extra, large, and small. Eggshells were white or brown. The eggs' farming system were defined according to the raising methods of laying hens and determined based on the label content, then grouped in three categories: conventional (battery cages), cage-free (including the free-range system known in Brazil as caipira), and organic.

For the information on labels, we analyzed the presence of pictures or other images, the presence of informative content, such as written descriptions of the product's quality or origin, and presence of certification seals. Regarding images on labels, the results were allocated in five groups: 1 - for no images, 2 - for images of eggs in various forms, 3 - for images of hens, 4 - for images of people (families, human figure in country outfits, celebrities) and 5 for others, which included labels with characters from cartoons that suggested an appeal for children. The results for written information were also allocated in groups for analysis: 1 - for no written content, 2 - for information about the farming methods and the hen's quality of life, and 3 - for information about the nutritional quality of the product.

Another question we aimed to answer was if labels with more information and details were related to more expensive eggs. In order to do that, we gave each label found a score based on the characteristics we analyzed: images, informative text or certification seals. A label with none of the features was given the score 0 . A label with only one of the features was allocated in score 1, a label with two features was scored 2 , and a score 3 was given to labels that had all three informations. We filtered the egg unit prices data using this score. The filter helped reduce bias, once we had many egg categories, and allowed us to focus on the variable in question: the label. Then, we calculated the average egg unit price for each scored label, and lastly, the average egg unit price for each score (0$3)$.

We performed the statistical analysis using the Statistical Analysis System software (SAS package 9.4). Initially, the normality of the residues was assessed through the Shapiro-Wilk test. For descriptive analyzes, the PROC MEANS procedure was used to define the means, medians, minimum, and maximum values. For comparative analysis of means, we used the PROC GLIMMIX procedure using Tukey test and ILINK option. The ILINK option from LSMEANS statement of PROC GLIMMIX was used to get estimates and their standard errors to be reported on the scale of the mean (the inverse linked scale). For the analysis of proportions of the information found on the labeling, the nonparametric Kruskal-Wallis test on ranks with 2 - sided multiple comparisons analysis after Dwass-Steel-CritchlowFligner was used. For that, the NPARIWAY procedure with the DSCF option was performed. All variables were evaluated according to the model:

$\mathrm{y}_{\mathrm{ij}}=\mu+\mathrm{T}_{\mathrm{i}}+\mathrm{a}_{\mathrm{j}}+\mathrm{e}_{\mathrm{ij}}$,

wherein: $Y_{i j}$ is the dependent variable; $\mu$ is the overall mean; $T_{i}$ is the fixed effect of system of production or egg features; $a_{j}$ is the random effect of supermarket, and $\mathrm{e}_{\mathrm{ij}}$ is the residual error with mean 0 and variance $\sigma 2$. The statistical significance adopted was $\mathrm{P} \leq 0.05$.

\section{Results and discussion}

\section{Egg categories available}

Along the project's data collection, we found 48 different brands or product lines (meaning different egg categories from the same brand) of table eggs available at São Paulo's west side supermarkets. Among those, 25 (52.1\%) came from conventional systems, based on caged hens, 16 (33.3\%) came from cage-free systems or pasture-raised method known as caipira, and $7(14.6 \%)$ were organic. We only found 2 brands that raised hens cage-free, but confined to indoor housing only, meaning $87.5 \%$ of the cage-free brands corresponded to free-range systems, with access to outdoor areas. 
Teixeira et al. (2018) found that Brazilian and Chilean consumers think of an ideal egg production farm as based on the following characteristics: animal welfare; natural housing or feeding; egg quality and its effect on consumers' health and nutrition; hygiene; production and economic aspects; ethical issues; and environmental concerns. Moreover, they found that many participants associated animal welfare and natural housing or feeding with egg quality and its effect on consumers' health and nutrition. Oberholtzer et al. (2006) observed, on similar survey carried out in the United States, that some participants believed that free-range and organic eggs have higher nutritional value than conventional eggs. In adition, few consumers expressed beliefs that the quality of treatment and the diet offered to the hens would affect eggs' taste and texture. Güney \& Giraldo (2019) reported that Turkish consumers were wiling to pay more for organic eggs, but not for functional eggs. This shows a tendency among consumers all over the world to think of food as a result of its background story, considering ethics in the animal handling, environmental impact, and processing conditions as much as the sensorial and sanitary quality.

Interestingly, our results corroborate that in Brazil battery cages are the most common production system, which has already been forbidden in many countries due its well know impact on animal welfare. It can be inferred that in a developing country, where eggs are a healthy, nutritive and cheap protein source, price is a higher concern for most consumers than any of the other aspects abovementioned. Kakimoto et al. (2013) showed that table eggs have suffered a progressive reduction in sale price, which has allowed significant improvement in low-income Brazilian families' diets.

\section{Pricing}

We found a large variation in sale price between different egg categories (Table 1). Overall, when comparing white and brown eggs, brown eggs were $66 \%$ more expensive, with an average numeric increase of $\mathrm{R} \$ 0.41$ per egg. However, when the eggshell colors were compared inside the farming system categories, there was no difference $(\mathrm{P}>0.05)$. There were no white organic eggs found at supermarkets throughout the research period.

The higher market price for brown eggs can be explained by the genetic differences between white and brown hens. The breeds for brown eggs are heavier, with higher maintenance energy and required a higher feed intake for the expected egg production, which increases production cost, and consequently, market price. Despite the fact that the breeds that produce brown eggs are slightly less productive, brown eggs are more valuable in the market (Kakimoto et al., 2013).

Table 1. Average of egg prices ( $\mathrm{R} \$$ per unit) according to eggshell color in each farming system.

\begin{tabular}{lcccc}
\hline & \multicolumn{2}{c}{ Eggshell color } & & SEM \\
\cline { 2 - 4 } Sistema & White & Brown & 0.057 & 0.3443 \\
Conventional & 0.63 & $0.71 \mathrm{C}$ & 0.243 & 0.7801 \\
Cage-free & 0.87 & $1.00 \mathrm{~B}$ & - & - \\
Organic & - & $1.47 \mathrm{~A}$ & - & \\
SEM & 0.231 & 0.047 & - & \\
P value & 0.5165 & $<0.0001$ & & \\
\hline
\end{tabular}

Average values followed by the same uppercase letter on the column and lowercase letter on the line do not showed differences according to Tukey's test $(\mathrm{P} \leq 0.05)$.

We also compared prices among the farming systems, regardless of eggshell color, package size, egg size, or other variables (Table 2). Regarding the hen's production system, there were significant differences in retail prices. Organic eggs were the most expensive, followed by cage-free eggs and, at last, the conventional eggs. The organic egg unit was $136 \%$ more expensive than the conventional egg and $52 \%$ more expensive than the cage-free egg. Cage-free eggs were 55\% more expensive than conventional eggs.

Conventional eggs are the cheapest because their production costs are lower. Battery cages allow higher production per square meter, smaller land requirement, well adapted high performance breeds, and abundant technology. Cage-free systems systems showed higher production costs because more space per hen is required. Free hens produce less eggs per square meter and the specific breeds that cope better to these systems usually require a higher feed intake to produce the expected amount of eggs. 
Inside this category, free-range eggs demand even more land use, because of the pasture or outside area requirement. Aditionally, Singh \& Cowieson (2013) states that the performance of free-ranged hens is related to the amount of consumed pasture. In Brazil, by legal standards, all organic hens are pastureraised. Organic eggs are the most expensive because, it has all the increased costs a free-range system has, and also needs to meet other legal standards, such as stocking density, feed origin, and composition, agricultural inputs, among others. The feed itself is a large limiting factor, as it must be certified organic, which can account for up to $70 \%$ of the cost of this production system, since organic grains are about 50-100\% expensive than conventional grain (Oberholtzer et al., 2006). Kristensen (1998) reported that organic egg production can be carried out quite efficiently in terms of egg production and feed conversion compared to conventional egg production in cages, although the feed consumption often is considerably higher. Moreover, the producer must pay for the certified organic seal in order to sell the product as organic, which involves extra annual fees, auditing costs, among other expenses, which contribute for the final price of the product.

Table 2. Descriptive and statistical analysis of egg prices (R\$ per unit) according to the hen's farming system, regardless of other variables.

\begin{tabular}{lccccc}
\hline Farming system & Mean & Median & SEM & Minimum & Maximum \\
\hline Conventional & $0.67 \mathrm{c}$ & 0.61 & 0.109 & 0.31 & 1.26 \\
Cage free & $0.99 \mathrm{~b}$ & 1.00 & 0.689 & 0.65 & 1.67 \\
Organic & $1.46 \mathrm{a}$ & 1.50 & 0.04 & 1.24 & 2.26 \\
SEM & 0.072 & & & & - \\
P value & $<0.0001$ & - & - & - & - \\
\hline
\end{tabular}

Means followed by different uppercase letters in the same column differ according to Tukey's test $(\mathrm{P} \leq 0.05)$.

Statistically, the price did not vary between size categories (small, large, extra, and jumbo) when analyzing the egg as a unit, even though a numeric difference was observed (data not shown). This is important since the size is related to the hen's age, meaning young hens lay smaller eggs and older hens lay bigger eggs ( Kakimoto et al., 2013).

Lastly, we analyzed the price differences for an egg unit when sold in different package sizes, inside each farming system category (Table 3). For 6 eggs packages, the highest sales price was for organic eggs, followed by cage-free and conventional eggs, those with no statistical difference between them. The same result was observed for 10 egg packages. However, for 12 and 20 eggs packages, there was no statistical difference among the three farming categories. For conventional eggs alone, being the largest category and offering all package sizes, we found the highest sale prices in 6 and 10 egg packages, with no statistical difference between them. This category was, followed by 12, 20 and 30 eggs package, once again without statistical difference, even though a significant numeric difference was observed. Karipidis et al. (2005) found similar results, which showed that egg units are more expensive when sold in smaller packages, in Greece. Also, they found the highest sale prices on organic and $\Omega 3$-enhanced eggs.

Table 3. Descriptive and statistical analysis of egg prices (R $\$ /$ unit) according to package size in each farming system.

\begin{tabular}{|c|c|c|c|c|c|c|c|}
\hline \multirow[b]{2}{*}{ Farming system } & \multicolumn{5}{|c|}{ Package size (units per package) } & \multirow[b]{2}{*}{ SEM } & \multirow[b]{2}{*}{$\mathrm{P}$ value } \\
\hline & 6 & 10 & 12 & 20 & 30 & & \\
\hline Conventional & $0.76 \mathrm{abB}$ & $0.86 \mathrm{aB}$ & $0.56 b$ & $0.60 \mathrm{~b}$ & $0.47 \mathrm{~b}$ & 0.101 & 0.0370 \\
\hline Cage-free & $0.90 \mathrm{~B}$ & $1.03 \mathrm{~B}$ & 0.67 & 0.68 & - & 0.316 & 0.6800 \\
\hline Organic & $1.48 \mathrm{~A}$ & $1.48 \mathrm{~A}$ & 1.13 & 1.00 & - & 0.444 & 0.9258 \\
\hline SEM & 0.13 & 0.078 & 0.54 & 0.341 & - & & \\
\hline$P$ value & 0.0009 & 0.0008 & 0.5790 & 0.7470 & - & & \\
\hline
\end{tabular}

Means followed by different uppercase letters in the same column differ according to Tukey's test $(\mathrm{P}<0.05)$.

\section{Label information}

Regarding images on labels, the most common category was score $2(29.2 \%)$, followed by score 1 and score 3 (each with $27.1 \%$ of the labels), and at last score $4(10.4 \%)$ and score $5(6.2 \%)$. Score number 3 , presenting images of hens, was exclusively found in cage-free and organic eggs. We did not find any labels with images of caged hens. 
The results for written information on the labels, group 1 was the most common group composing $50 \%$ of the labels, $41.7 \%$ the labels were from group 2, and group 3 had $8.3 \%$ of the labels. Group number 2 , regarding information about animal handling methods, was exclusively found in cage-free and organic eggs. $87.5 \%$ of the cage-free egg brands gave details about the farming process on the label, while for organic eggs that percentage was $85.7 \%$. For conventional eggs, none of the brands gave information about the production system itself, but $16 \%$ of the brands talked about the nutritional value of the product on the label.

These results corroborate the suggestion that ethical raising methods are a differential and an appeal to the product, as only cage-free and organic eggs gave details about the production system on the label. It is plausible to assume that describing a battery cage system or using an image of it on the label may not be appealing to the consumer, contributing for the absence of this information of all battery cages eggs' label. Moreover, we grouped the information for each of the six kinds of certification seals found (Table 4). They were: SisOrg (Brazilian national certified organic seal), Certified Humane Brasil (animal welfare certified seal), Clube dos Produtores (specific seal for members of the Walmart group), Rastreabilidade Paripassu (traceability QR code), WQS (regarding the certification for antibiotic-free production), and Associado AVAL (declaring that the company is a member of the Brazilian Association for Alternative Aviculture). The Orgânicos Brasil seal was found in all organic eggs, meaning there were no irregularities such as eggs being sold as organic without proper certification.

Table 4. Proportion of certification seals in each farming system.

\begin{tabular}{lcccc}
\hline \multirow{2}{*}{ Seal/certification } & \multicolumn{3}{c}{ Farming system } & \multirow{2}{*}{$\mathrm{P}^{*}$ value $^{1}$} \\
\cline { 2 - 4 } Orgânicos Brasil & Organic & Cage-free & Conventional & 0.0001 \\
Certified Humane & $100.0 \% \mathrm{a}$ & $0.00 \% \mathrm{~b}$ & $0.00 \% \mathrm{~b}$ & 0.0001 \\
Clube dos Produtores & $13.0 \% \mathrm{~b}$ & $71.42 \% \mathrm{a}$ & $0.00 \% \mathrm{c}$ & 0.4850 \\
Rastreabilidade Paripassu & $0.00 \%$ & $6.45 \%$ & $0.00 \%$ & 0.2818 \\
WQS & $6.67 \%$ & $0.00 \%$ & $0.00 \%$ & 0.1635 \\
Associado AVAL & $14.28 \%$ & $6.67 \%$ & $0.00 \%$ & 0.1635 \\
\hline
\end{tabular}

Means followed by different lowercase letters in the same row differ according to Kruskal-Wallis test after DSCF multiple comparison procedure $(\mathrm{P} \leq 0.05)$.

The variety of seals found on labels was impressive and can indicate growing consumer interest in third-party audits of that product's quality. In Brazil, there are mandatory contents that should be present on any egg package label, such as list of ingredients, best by date, cooking instructions, among others (BRASIL, 2020). These contents were found in all analyzed products. However is not mandatory to give the consumer information about the farming system, animal handling practices, feed composition, residue management, or other key details that may affect the consumer's decision. Brands that choose to give details about the farming process on the label, or better yet, get certified on special features that improve the product's quality, add value and differentiate themselves from other brands. When a company certifies its product, it assumes that the information it provides is important to consumer's choice and that they will respond by altering their purchasing decisions based on it (Conceição \& Barros, 2005). Companies have also found that consumers will pay premium prices for products with special nutritional claims on their labels, a behavior that is believed to be a result of a combination of focus on consumer health, environmental concerns, and issues from animal welfare groups (Branch \& Dharmasena, 2019). It is important to highlight that each certification seal adds cost value to the product, which should be reflected on a higher sale price.

These results are relevant for food traceability mechanisms as well, even setting a seal category of its own. Badia-Melis et al. (2015) defined traceability as the ability to access any or all information relating to that which is under consideration, throughout its entire life cycle, by means of recorded identifications. Food traceability is of high potential for consumer's protection by targeting precisely the recall, eliminate the non-consumable food products and promoting the investigation of the causes of food safety issues; all of that by being an integral part of food safety, food quality, food defence and intrinsic requirement of the food supply chain. Traceability is an important component of contemporary supply chains in the production industry, and in food sector, particularly sensitive from human and animal health point of view (Bosona \& Gebresenbet, 2013). Moraes et al. (2007) studied egg labels in 
Rio de Janeiro, and reported that many brands did not declare pack date or lot code, which strongly compromises traceability.

Lastly, we found that more detailed labels had higher average prices for the egg unit. The average egg for score 0 was $\mathrm{R} \$ 0.62$, for score $1 \mathrm{R} \$ 0.83$, for score $2 \mathrm{R} \$ 1.03$, and score $3, \mathrm{R} \$ 1.26$ (Figure 1).

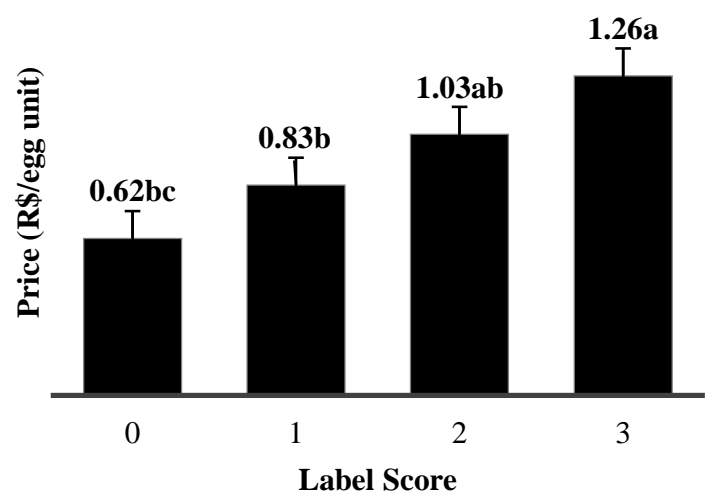

Figure 1. Relationship between egg unit price with level of detail found on labels of different brands. The label details were gathered into having 4 score levels: $0=$ no images; $1=$ images; 2 = images and informative text; and 3 = images, informative text, and certification seals. Means were compared according to Tukey's test $(\mathrm{P} \leq 0.05)$.

\section{Conclusions}

We concluded that there is a wide variety of categories available for the table egg market on the west side of the city of São Paulo, differentiating themselves in farming system, eggshell color, egg and package size, among others. Prices vary among the categories, specially comparing farming systems. In addition, we found that not only the presence of information and certification seals on labels showed a higher interest from the brand to be transparent about their farming system, but also, we have observed that more detailed labels are related to more expensive eggs.

Once we have characterized the table egg market on the west side of the city of São Paulo, the next step would be a survey with consumers, to understand how they see each egg category, what they value on a label, what they understand from the presence of a certification seal, and what characteristics of the product are most important for their purchasing decision. A larger survey, investigatin a larger number of supermarkets and different cities, would benefit our data and analysis, contributing for a more integrative understanding of eggs' market." imediatamente após "purchasing decision

\section{References}

Associação Brasileira de Proteína Animal (ABPA). Relatórios Anuais. (2019). Disponível em $<$ http://abpa-br.org/mercados/>.

Badia-Melis, R., Mishra, P., \& Ruiz-García, L. (2015). Food traceability: New trends and recent advances. A review. Food Control, 57, 393-401. https://doi.org/10.1016/j.foodcont.2015.05.005.

Bosona, T., \& Gebresenbet, G. (2013). Food traceability as an integral part of logistics management in food and agricultural supply chain. Food Control, 33(1), 32-48. https://doi.org/10.1016/j.foodcont.2013.02.004.

Branch, M., \& Dharmasena, S. (2019). Factors affecting the propensity to purchase specialty eggs in the United States. Journal of Food Distribution Research, 50(856-2019-3202), 114-122. https://doi.org/10.22004/ag.econ.292191.

BRASIL. Instrução Normativa $n^{\circ}$ 67, de 14 de dezembro de 2020. Altera e retifica o anexo da Instrução Normativa MAPA n ${ }^{\circ} 22$, de 24 de novembro de 2005.

Buriak, R., Rudenko, M., \& Chornodid, I. (2018). Marketing research of table eggs market. Baltic 
Journal of Economic Studies, 4(4), 69-75. https://doi.org//10.30525/2256-0742/2018-4-4-69-75.

Conceição, J. C. P. R., \& Barros, A. L. M. (2005). Certificação e rastreabilidade no agronegócio: instrumentos cada vez mais necessários. Instituto de Pesquisa Econômica Aplicada, 1, n. 1122.

Güney, O. I., \& Giraldo, L. (2019). Consumers' attitudes and willingness to pay for organic eggs. British Food Journal, 122(2), 678-692. https://doi.org/10.1108/BFJ-04-2019-0297.

Kakimoto, S. K., Souza Filho, H. M., Pizzolante, C. C., \& Moraes, J. E. (2013). Determinantes da competitividade da cadeia produtiva do ovo no estado de São Paulo. Informações Econômicas, 43(6), $46-56$.

Karipidis, P. I., Tsakiridou, E., Tabakis, N. M., \& Mattas, K. (2005). Hedonic analysis of retail egg prices. Journal of Food Distribution Research, 36(856-2016-56442), 68-73. https://doi.org/10.22004/ag.econ.27760.

Kristensen, I. (1998). Organic egg, meat and plant production-bio-technical results from farms. Techinal Report of the Danish Institute of Agriculture Science, 1, 95-169.

Moraes, I. A., Mano, S., \& Baptista, R. F. (2007). Análise da rotulagem de ovos comercializados na cidade do Rio de Janeiro-Brasil. Revista Brasileira de Ciência Veterinária, 14(1), 7-11. https://doi.org/10.4322/rbcv.2014.221.

Oberholtzer, L., Greene, C., \& Lopez, E. (2006). Organic poultry and eggs capture high price premiums and growing share of specialty markets. Economic Research Service, LDP-M-150, 1-18.

Singh, M., \& Cowieson, A. J. (2013). Range use and pasture consumption in free-range poultry production. Animal Production Science, 53(11), 1202-1208. https://doi.org/10.1071/AN13199.

Tanner, R., \& Purcell, D. (2010). The state of the specialty food industry 2010. Specialty Food Magazine, 40(3), 3A-16A.

Teixeira, D. L., Larraín, R., \& Hötzel, M. J. (2018). Are views towards egg farming associated with Brazilian and Chilean egg consumers' purchasing habits? PloS One, 13(9), e0203867. https://doi.org/10.1371/journal.pone.0203867.

Histórico do artigo:

Received: March 2, 2021

Accepted: March 23, 2021
License information: This is an open-access article distributed under the terms of the Creative Commons Attribution License 4.0, which permits unrestricted use, distribution, and reproduction in any medium, provided the original work is properly cited.. 